\title{
Pulse ingredients supplementation affects kefir quality and antioxidant capacity during storage.
}

Linda Ould Saadi ${ }^{1,3,4}$, Farid Zaidi ${ }^{1}$, B. Dave Oomah ${ }^{2}$, Monika Haros ${ }^{3}$, Maria Jesus Yebra ${ }^{3}$, Farah Hosseinian $^{4 *}$

${ }^{1}$ Departement des Sciences Alimentaires, Faculté des Sciences de la Nature et de la Vie, Université de Bejaia, 06000 Bejaia, Algérie

${ }^{2}$ (Retired) Formerly with the National Bioproducts and Bioprocesses Program, Pacific AgriFood Research Centre, Agriculture and Agri-Food Canada, Summerland, BC, Canada V0H $1 Z 0$

${ }^{3}$ Institute of Agrochemistry and Food Technology (IATA-CSIC) Valencia, Spain.

${ }^{4}$ Food Science and Nutrition Program, Chemistry Department, 1125 Colonel By Drive, Carleton University, Ottawa, Ontario, Canada, K1S $5 B 6$

*Corresponding author. Tel: 1-613-520-2600 x 2048; Fax: 1-613-520-3749.

E-mail: farah_hosseinian@carleton.ca (F. Hosseinian). 


\begin{abstract}
1 Changes in kefir storage $\left(4^{\circ} \mathrm{C}, 28\right.$ days) were evaluated every week in response to pulse

2 (whole faba bean [Vicia faba L. minor] and its dehulled fractions - hulls and cotyledon; whole

3 chickpea [Cicer arietinum L.)] and its crude mucilage) supplementation. Each supplement

4 offered different profile of microbial count that was optimal at 14 days refrigerated storage.

5 Bacterial growth was insignificant for faba bean hull and cotyledon supplemented kefirs

6 between $7-21$ days storage. Titratable acidity (TTA) of kefirs decreased for the first week then

$7 \quad$ increased with increased storage time at different rates for each supplement. Kefir $\mathrm{pH}$ decreased

8 linearly with storage time with significant differences observed among samples after 14 days

9 storage. Inulin and other supplementations improved the production of Lactate and increased

10 proteolytic activity with fermentation time. Antioxidant activity of kefir depended solely on the

11 phenolic content and antioxidant activity of the supplements independent of storage time.

12 Moreover, pulse supplements were superior to commercial inulin in maintaining kefir stability

13 during refrigerated storage.
\end{abstract}

14

15 Keywords: Kefir, Antioxidant, Survival Bacteria, Proteolytic activity, Organic acid. 


\section{Introduction}

Kefir is gaining prominence because of the numerous health benefits attributed to the prominent probiotic effects especially on gut health. Moreover, kefir can improve cardiovascular disease risk profile of young adults ( 18 - $24 \mathrm{yr}$ ) by attenuating C-reactive protein increase due to enhanced kefir digestibility resulting from lactose reduction by fermentation (O’Brien et al., 2015). Probiotic treatment also rescued neurogenesis and cognitive function in antibiotic treated mice by predominantly promoting progenitor cell survival in the brain (Möhle et al., 2016). These developments have spurred the food industry to invest in kefir beverages as the second generation of probiotic products. Thus, recent novelty in kefir is the new line of protein kefir drinks (20 g protein /8 oz serving) with reduced fat containing a combination of inulin and pectin as fat mimetics to bulk viscosity and increase satiety (Shelke, 2016). The veggie (beets, cucumber or tomato purees) kefir line took advantage of the vegetable's cellular matrices to reduce the amount of added sugar. Various protein-and polysaccharide-based ingredients have been developed to replace the physicochemical and sensory properties provided by fats. These ingredients, typically made of indigestible dietary fibers with relatively low-calorie contents can provide added health benefits and some are believed to induce greater satiety than fats(Shelke, 2016).

Pulses play important role in food and nutrition because of numerous health benefits and are being incorporated into many popular food categories. This promotes domestic demand of pulses as a strategy to contain the soaring healthcare costs, enhance long-term health outcomes and accelerate the nutritional improvements of industrial food products. Pulses have yet to make inroads into the probiotic food category due to limited research studies. For example, lactic acid fermentation has been successfully applied to pulse flours including faba bean and chickpea, resulting in reduced antinutritional compounds, increased free essential amino acids and improved in vitro protein digestibility (Coda et al., 2015). In yogurt production, 
pulse ingredients including chickpea flour favored acidification by probiotic bacteria by improving lactobacilli growth (Zare, Champagne, Simpson, Orsat, \& Boye, 2012).

Kefir is an excellent vehicle to deliver pulse ingredients to consumers; however, viability of probiotic organisms must be maintained within an appropriate shelf-life to be beneficial to health. Previously, we found that faba bean flour supplementation (4\%) stimulated bifidogenic microbial growth, increased titratable acidity linearly from day 1 to 21 , and reduced pH during kefir storage for 28 days (Boudjou, Zaidi, Hosseinian, \& Oomah, 2014). Subsequent studies with air-classified faba bean fractions demonstrated more efficient Lactobacillus plantarum growth in the starch rich than in the fiber fraction; protein enriched fraction exerted the highest lactic acid and acetic acid production and TTA indicating strong buffering capacity (Coda et al., 2015). Our investigation therefore aimed at evaluating the effects of supplementing whole faba bean flour, its cotyledon and hull fractions, chickpea flour and its mucilage on kefir stability during refrigerated storage for 28 days. Chickpea mucilage was included in the study because water-soluble polysaccharide extracted from chickpea flour has been reported to display good anti-hypertensive activities and can be used as a thickening or functional agent in food systems (Mokni Ghribi et al., 2015). Inulin was also included in our investigation since it has been extensively studied, granted blood glucose claim in Europe and provides the best evidence of prebiotic effects in human (Crane, 2016). The development of pulse-based kefir is contingent on demonstrating the prebiotic effects of the pulse ingredient/s relative to commercially available prebiotic such as inulin, the capacity of these ingredients to maintain their prebiotic effect during storage and enhance other bioactivities that can confer additional human health benefits. 


\section{Materials and method}

Faba bean (Vicia faba L.) subspecies minor and chickpea (Cicer arietinum L.) samples were from Skikda and Oeud Amizour Wilaya of Bejaia, Algeria, respectively. Faba bean seeds were cleaned, air dried, and manually separated into hulls and cotyledons. All samples were initially crushed in a traditional stone mill followed by an electric coffee mill (Moulinex, France) then sieved (Tap sieve shaker AS 200; Retsch GmbH, Haan, Germany) to pass a 500 $\mu \mathrm{m}$ screen. The powders were stored in the fridge in sealed plastic bags until analysis.

\subsection{Chickpea crude mucilage extraction}

Ground chickpea was extracted with distilled water $(1: 40, \mathrm{w} / \mathrm{v})$, stirred for $3 \mathrm{~h}$ at $60{ }^{\circ} \mathrm{C}$, extracts allowed to cool to room temperature then centrifuged (4000g, $20 \mathrm{~min}$; Sorvall Legend XTR centrifuge, Thermo Scientific, Ashville, NC, USA). The supernatant was considered as the crude mucilage and used for further analysis. 2.2. Phenolic extraction and analysis

\subsection{Phenolic extraction and analysis}

Phenolics were extracted with $95 \%$ acidified $(1 \mathrm{~N} \mathrm{HCl})$ methanol as described previously (Hosseinian \& Mazza, 2009). Briefly, defatted samples (1 g) were extracted with methanol (20 $\mathrm{ml})$ by magnetic stirring for $6 \mathrm{~h}$ at room temperature. The extract was centrifuged $(4000 \mathrm{~g}, 15$ min; Sorvall Legend XTR, Thermo Scientific, Ashville, NC), the supernatant recovered and stored in the fridge until analysis.

Total phenolics of the methanol extracts were determined by the Folin-Ciocalteau method (Singleton \& Rossi, 1965). Absorbance of samples and gallic acid standards (0 - 0.9 $\mathrm{mg} / \mathrm{ml}$ prepared in $80 \%$ ethanol) was monitored at $725 \mathrm{~nm}$ (Cary 50 Bio UV-visible Spectrophotometer, Varian, Mulgrave, Australia). Samples were analyzed in triplicates and results expressed in mg gallic acid equivalents (GAE)/g sample.

The $\mathrm{AlCl}_{3}$ method (Lamaison \& Carnet, 1990) was used for determination of total flavonoid content of the methanol extracts. Aliquots $(2 \mathrm{ml})$ of extracts were added to equal 
volumes of a solution of $2 \% \mathrm{AlCl}_{3} \cdot 6 \mathrm{H}_{2} \mathrm{O}(2 \mathrm{~g} / 100 \mathrm{ml}$ methanol $)$. The mixture was vigorously shaken, and absorbance was monitored at $430 \mathrm{~nm}$ after $15 \mathrm{~min}$ incubation using quercetin $(0-$ $0.013 \mathrm{mg} / \mathrm{ml}$ in $80 \%$ ethanol) as standard. Flavonoid content was expressed in $\mathrm{mg}$ quercetin equivalents/g sample.

\subsection{HPLC analysis of phenolic compounds}

Chemicals (acetonitrile, formic acid) used for high-performance liquid chromatography (HPLC) were of chromatographic grade (Sigma-Aldrich Canada Ltd., Oakville, ON, Canada). Analysis of phenolic acids in the methanol- $\mathrm{HCl}$ extracts of legume powders was carried out on an HPLC (Alliance Waters 2695) system equipped with photodiode array detector (PDA, Waters 2998), Empower software, and auto sampler (Waters Corp., Milford, MA). The separation was carried out with an Atlantis RT3 column (150 mm x $4.6 \mathrm{~mm}, 5 \mu \mathrm{m}$ particle size; Waters, Milford, MA). Chromatographic separation was carried out with $10 \mu 1$ extract using two solvent systems: (A) water: formic acid (99.99:0.01, v/v) and (B) acetonitrile 100\% at 1.23 $\mathrm{ml} / \mathrm{min}$ and $30{ }^{\circ} \mathrm{C}$. The gradient conditions were as follows: solvent $\mathrm{B}$ : $0 \mathrm{~min}, 10 \% ; 35 \mathrm{~min}$, 50\%; $40 \mathrm{~min}, 90 \%$. The chromatograms were recorded at 254, 280, 320 and $520 \mathrm{~nm}$ for phenolic acids and flavonoids, respectively. Phenolics were quantified using authentic commercial compounds supplied by Sigma Aldrich Chemicals (St.Louis, MO, USA). Concentration of phenolic compounds were determined from the average of three replicate chromatograms and expressed in $\mathrm{mg} / \mathrm{g}$ sample.

\subsection{Oxygen radical absorbance capacity (ORAC)}

Antioxidant activity was measured using the radical absorbance capacity (ORAC $\left.\mathrm{FL}_{\mathrm{F}}\right)$ described previously (Agil \& Hosseinian, 2012), according to established procedure (Prior et al., 2003). A multi-detection microplate fluorescence reader (BioTek Instruments, Ottawa, ON,

Canada) was used with excitation and emission wavelengths at 485 and $525 \mathrm{~nm}$, respectively. Sample extracts and Trolox (6-hydroxy-2,5,7,8-tetramethylchroman-2-carboxylic acid, Sigma- 
117 Aldrich Canada Ltd., Oakville, ON, Canada) standards were diluted with $75 \mathrm{mM}$ phosphate

118 buffer ( $\mathrm{pH}$ 7.4) prior to transfer into a 96-well microplate (Fluotrac 200, Greiner Bio-One Inc.,

119 Longwood, FL). A peroxyl radical was generated by AAPH [2,2'-azobis (2-

120 methylpropionamide) dichloride] (Sigma-Aldrich, St. Louis, MO) during measurement, and

121 fluoresceine was used as the substrate. Measurements were taken after 60 min at $37{ }^{\circ} \mathrm{C}$ upon

122 addition of AAPH. Final ORAC values were calculated using a regression between the Trolox

123 concentration $(0-6 \mu \mathrm{g} / \mathrm{ml})$ and the net area under the curve and expressed as $\mu \mathrm{M}$ Trolox 124 equivalents (TE)/g sample.

For kefir, samples $(1 \mathrm{ml})$ were extracted $\left(25^{\circ} \mathrm{C}, 1 \mathrm{~h}\right)$ with $80 \%$ aqueous ethanol $(10 \mathrm{ml})$,

126 filtered (Whatman No.4), and the residue re-extracted (10 $\mathrm{ml} 80 \%$ aqueous ethanol). The

127 combined extracts were centrifuged (4000g, $10 \mathrm{~min}$; Sorvall Legend XTR centrifuge, Thermo

128 Scientific, Ashville, NC, USA), and the supernatant used for ORAC analysis.

\subsection{Kefir preparation}

130 The freeze-dried starter kefir culture (kefir type B-heterofermentative culture-without 131 production of $\mathrm{CO}_{2}$ containing Lactobacillus plantarum, Lactobacillus rhamnosus, Lactoccocus

132 lactis subspecies lactis and cremosis and Leuconostoc cremosis (Abiasa Inc., Saint Hyacinthe,

133 Quebec, Canada) was used in this study. The culture was diluted in pasteurized, homogenized 134 (3.25\% fat) milk purchased locally from a commercial source (Ottawa, ON, Canada), stirred at $13585^{\circ} \mathrm{C}$ for $15 \mathrm{~min}$, portioned into sterile conical tubes $(50 \mathrm{ml})$, and cooled to $42{ }^{\circ} \mathrm{C}$ (Espírito 136 Santo et al., 2010). Seven treatments were prepared containing three faba bean (whole, 137 cotyledon and hull), and chickpea flours $(1.5 \mathrm{~g} ; 3 \%$, w/v), chickpea mucilage, inulin (10 ml 138 added to $40 \mathrm{ml}$ milk) and the control without any additives. The inoculated milk samples were 139 prepared in triplicate, incubated overnight at room temperature and stored refrigerated $\left(4{ }^{\circ} \mathrm{C}\right)$ 140 for 28 days. 
The Kefirs were subjected to physicochemical and microbiological analysis, using

144 methodologies published elsewhere being easily available: $\mathrm{pH}$, TTA, the bacterial 145 enumerations were carried out once a week for a total of 4 weeks $(1,7,14,21$, and 28 days) in 146 triplicate for each batch at different dilutions (four serial dilutions of 1/10). From each dilution, 147 a $100 \mu 1$ aliquot was plated on MRS agar (Sigma-Aldrich Canada Ltd., Oakville, ON, Canada) 148 as described previously (Espírito Santo et al., 2010), incubated ( $\left.37^{\circ} \mathrm{C}, 24 \mathrm{~h}\right)$, and colony counts 149 converted to $\log \mathrm{cfu} / \mathrm{ml}$.

\subsubsection{Determination of proteolytic activity}

Proteolytics activitis of starter culture of Kefir with differentes formulation assessed by measuring liberated amino acids and peptides using the O- phthaldialfdehyde (OPA) methode

153 (Donkar, Nilmini, Stolic, Vasiljevic \& Shah, 2007). The protelytic activity was expressed as 154 the absorbance of OPA derivatives at 340nm.

\subsubsection{Determination of organic acids}

Determination of lactic, acetic, butyric and propionic acids was carried out using the method described previously (Sarmiento-Rubiano, Zúñiga, Pérez-Martínez, \& Yebra, 2007). Briefly, $1 \mathrm{ml}$ of kefir samples from different days of storage $(1,7,14,21$, and 28 days) were resuspended in $9 \mathrm{ml}$ of phosphoric acid $(0.1 \%, \mathrm{pH} 2.4)$, vortexed and centrifuged at $9000 \mathrm{~g}$ for $20 \mathrm{~min}$ at $2^{\circ} \mathrm{C}$. Supernatants were filtred throught Einmalfilter $0.45 \mu \mathrm{m}$ filter unit (chromafil, Germany) and injected in HPLC (Jasco Corporation, Japan) with a UV detector at $210 \mathrm{~nm}$. Samples were loaded in a Rezex ROA Organic Acid column (Phenomenex,USA) placed at $30^{\circ} \mathrm{C}$ and phosphoric acid $0.1 \%, \mathrm{pH} 2.4$, was used as the mobile phase in isocratic conditions. general linear models (GLM) procedure, means comparison by Duncan's test, Pearson 
correlation, and variance component analysis (VARCOMP) were performed according to

159 Statistical Analysis System, SAS 9.1 for Windows (SAS Institute Inc, 1990).

\section{Results and Discussion}

\subsection{Phenolics and antioxidant activity}

The hull and cotyledon represented $14.2 \%$ and $85.1 \%(\mathrm{w} / \mathrm{w})$ of Vicia faba minor,

respectively in accordance with our previous study(Boudjou, Oomah, Zaidi, \& Hosseinian, 2013). Faba bean hulls and cotyledons had the highest and lowest concentration, respectively of total phenolics and flavonoids (Table 1) exhibiting the highest antioxidant activity among the faba bean fractions. Total phenolic content of faba bean hulls were four times those in the whole seeds and nine-fold their concentration in cotyledons and within the range reported for Tunisian faba bean hulls (Chaieb, González, López-Mesas, Bouslama, \& Valiente, 2011).

169 Flavonoids also concentrated in the hulls with over fivefold the content in whole faba beans.

170 These trends were similar to those reported earlier for acetone extracts of faba bean fractions

171 (Boudjou et al., 2013). Antioxidant activity of the whole faba bean was within the range of

172 those reported for Canadian genotypes(Oomah et al., 2011). Whole chickpea displayed the

173 lowest total phenolic content, although its flavonoid and ORAC values were not significantly

174 different from those of faba bean cotyledons. However, our results for chickpea phenolics and 175 antioxidants were higher than those reported previously (Xu \& Chang, 2007). The yield of 176 aqueous extract from chickpea-hereby considered as mucilage was $28.4 \%$. It had twice the

177 flavonoid content of whole chickpea and exhibited the lowest antioxidant activity (Table 1).

178 The antioxidant activity of the samples correlated significantly ( $\mathrm{r} 2=0.899$ and $0.874 ; \mathrm{P}<$

179 0.0001) with total phenolic and flavonoid contents, respectively.

180 The phenolic HPLC profile of whole faba beans and cotyledon was closely related with the

181 latter devoid of three flavonoids: epicatechin, quercetin and quercetin $3 \beta$-glucoside (Table 2).

182 This is similar to closely associated phenolic pattern of faba bean cotyledon and whole seeds 
183 reported earlier (Bekkara, Jay, Viricel, \& Rome, 1998). The cotyledon generally had 184 significantly $(\mathrm{P}<0.05)$ higher phenolic acids, except gallic acid, but lower flavonoids than the 185 whole faba bean seeds. Faba bean hull was the richest flavonoid source due to its high catechin, 186 epicatechin and rutin content; it also had the highest gallic and protocatechuic acids and 187 pyrogallol in addition to being the only sample containing coumaric and hydroxybenzoic acids 188 and kaempferol. The highest flavonoid concentration of TF (Table 2) corresponded with the 189 highest content observed among all samples (Table 1). High concentrations of chlorogenic acids were present in faba bean cotyledon and seed, representing almost $50 \%$ of the total phenolic acids. The presence of catechin, epicatechin, and quercetin in faba bean is consistent with

192 previous report (Baginsky et al., 2013). Flavonoid concentration was over two and half times

193 higher than those of phenolic acids in chickpea due to the high quercetin and myricetin contents.

194 Pyrogallol and epicatechin were the only phenolic compounds identified in chickpea mucilage.

195 Quercetin, myricetin, gallic and vanillic acids representing major chickpea phenolic 196 constituents have also been previously reported (Sreerama, Sashikala, \& Pratape, 2010).

\subsection{Physicochemical and Microbial analysis}

198 Two factors: supplement (samples) and storage time were studied to further elucidate the

199 variability in kefir storage parameters. Variance component analysis revealed that storage time 200 predominantly contributed to the variation in microbial growth $(73 \%)$, TTA $(73 \%)$ and $\mathrm{pH}$ 201 (97\%) (fig.2). The optimal (8.1 - $8.7 \log \mathrm{cfu} / \mathrm{ml})$ and minimal (7.3 - $7.7 \mathrm{log} \mathrm{cfu} / \mathrm{ml})$ microbial 202 count occurred on storage days 14 and 1, respectively for all kefirs (Fig. 1). Titratable acidity 203 (Fig. 2a) was found to be highly inversely correlated $(\mathrm{r}=-0.789$ to $-0.868 ; \mathrm{P}<0.0005)$ with $\mathrm{pH}$ 204 (Fig. 2b) for all faba bean supplemented kefirs and chickpea supplemented kefir suggesting that $205 \mathrm{pH}$ reduction favored acidification probably resulting from amino acid release through protein 206 hydrolysis (Baik \& Han, 2012; Coda et al., 2015). 
This study confirmed our earlier report(Boudjou et al., 2014) that faba bean supplementation

208 maintains cell viability during extended kefir storage. The rapid TTA decline and simultaneous

209 microbial growth during the first week of storage $(\mathrm{d} 1-\mathrm{d} 7)$ corresponds to the behavior of

210 different microbial community, particularly the lactic acid and acetic acid bacteria found in

211 Brazilian kefir (Leite et al., 2013). Faba bean hull and cotyledons, in particular, maintained

212 microbial stability during $7-21$ days kefir storage. Furthermore, the highest TTA increase

213 during faba bean cotyledon supplemented kefir storage infers that its highly fermentable

214 raffinose family oligosaccharides (Quemener, 1988) were readily available to kefir

215 microorganisms. The higher microbial counts of legume-supplemented kefir demonstrate their

216 superior prebiotic effect compared to inulin during refrigerated storage. The superior

217 performance of faba bean and chickpea compared to inulin supplementation during kefir storage

218 suggests that these legumes provide an opportunity for their development and use as prebiotic

219 s similar to those of the well-established inulin.

220 The high microbial count $(\geq 7.4 \mathrm{log} \mathrm{cfu} / \mathrm{ml})$ after 28 days kefir storage was above the

221 recommended level $(\geq 6-7 \log \mathrm{cfu} / \mathrm{ml})$ required for probiotic food suggesting that the

222 supplemented kefirs can exert the probiotic health benefits to the host and therefore applicable

223 for health claim (Matejčeková, Liptáková, \& Valík, 2017)

\subsection{Proteolytic activity of starter culture of Kefir}

225 Proteolytic activity varied significantly $(\mathrm{P}<0.0001)$ among kefir samples, storage time and 226 their interactions. However, storage time accounted for the highest total variation (57\%) 227 compared with kefir treatments and their interactions (17 and 18\%, respectively). The mean 228 (average) proteolytic activity of kefirs increased linearly $(r=0.99)$ with storage time $(1-21$ days $)$

229 (Table 3). This linear increase $(r \geq 0.96)$ was also observed for whole faba bean, faba bean hull, 230 chickpea and chickpea mucilage supplemented kefirs during storage (1-14 days). Proteolytic 231 activity of chickpea mucilage supplemented kefir was not significantly different from the 
control kefir during storage, except at the 14th day. Similarly, whole faba bean, faba bean

233 cotyledon and chickpea flour supplemented kefir did not differ significantly in proteolytic

234 activity during storage with few exceptions. Faba bean hull supplemented kefir had proteolytic

235 activity not significantly different than those with inulin during 1-14 days storage suggesting

236 similar prebiotic effect in releasing peptides and amino acids associated with proteolytic

237 activity (Ramchandran \& Shah, 2010).

\subsection{Production of organic acids}

The analysis of variance for organic acids showed that kefir samples (treatments), storage time and their interactions were all highly significant $(\mathrm{P}<0.0001)$. The variance in lactic acid was predominantly associated with kefir treatment (49\% of the total variation), higher than that of storage time (29.7\%) and their interaction (15.7\%). The variance associated with kefir treatment, storage time and their interactions were 14.3, 58.9 and $18.1 \%$ (of the total variation), respectively for butyric acid; and 39.6, 38.2, and 21.8\% (of total variation), respectively for acetic acid. Kefir treatment, storage and their interaction had no significant

247 effect on the variability of propionic acid, since their variance $(25,20$ and $10 \%$ of the overall 248 variation, respectively) was smaller than that of the experimental error (44.4\%).

249 Chickpea and whole faba bean flour supplementation produced the highest amount of lactic and 250 butyric acids at 14 days storage. Acetic acid was highest with chickpea flour (1-14 days 251 storage), although consistently high concentration occurred with faba bean hull 252 supplementation. Chickpea mucilage generally produced lower amounts of organic acids than 253 the chickpea flour. Acetic acid production was induced by faba bean hulls since the cotyledons 254 had the lowest concentration (days 7 and 14) or levels similar to the control kefir (days 1 and 255 21). Kefir containing faba bean hull and whole faba bean flour had the highest and lowest 256 propionic acid content (21 day storage), respectively; although differences among kefir 
treatments were generally not significant. Lactic acid production decreased linearly $(r=\geq 0.91)$ with storage time (7-28 days) for the control kefir and kefir supplemented with inulin, faba bean cotyledons and chickpea mucilage; increased linearly $(r=0.997)$ with storage time (1-14 days) for whole faba bean flour and remained unchanged during storage (1-21 days) for faba bean hulls (Table 4). Acetic acid content increased linearly $(r=\geq 0.94)$ with storage (1-14 days) for kefir supplemented with chickpea and faba bean cotyledon flours and decreased linearly $((\mathrm{r}=$ $\geq 0.95)$ with storage for inulin (7-28 days) and whole faba bean flour (14-28 days). Butyric acid also increased linearly $(r=\geq 0.94)$ with storage (1-14 days) for the control kefir and the chickpea and faba bean hull supplemented kefirs.

The molar ratios of the SCFAs, acetic, propionic and butyric acids changed during storage reflecting differences in kefir microbiota; the change was highly dependent on the prebiotic supplement and occurred often on the $21^{\text {st }}$ day. The molar ratio of acetate decreased (64 to $50 \%$ ) with concomitant increase in butyrate (27 to $38 \%$ ) and propionate (9 to $12 \%$ ) during storage (128 days) of the control kefir. These changes may be due to the significant decrease in L.acidophilus and Bifidobacterium sp. reported during cold storage of kefir for 21 days (KökTaş, Seydim, Ozer, \& Guzel-Seydim, 2013). Whole faba bean flour supplementation induced the greatest changes in molar ratios of acetate: propionate: butyrate (from 70:7:23 [day 1] to 45:8:47 day 28]) during storage, whereas minimal changes in SCFAs molar ratio occurred with chickpea flour supplementation. Changes in SCFAs molar ratio were similar for inulin (from 72:6:22 to $63: 7: 30$ ) and chickpea mucilage (from 70:8:22 to 59:12:28z) supplemented kefir during storage suggesting the significant beneficial effect on the viability of bifidobacteria observed after 28 days of refrigerated storage of fermented milk (Varga, Szigeti, \& Gyenis, 2006). Faba bean hull was the only treatment that increased acetic acid and concomitantly decreased propionic and butyric acids ratios (from 50:13:37 to 77:5:18; difference between the $1^{\text {st }}$ and $28^{\text {th }}$ storage days), although the molar ratios remained almost constant ( 7 to 21 days 
282

283

284

storage). However, butyrate yield from faba bean hull was significantly higher than the control kefir during storage (1-14 days) indicating the potential beneficial effects of this natural fiber. In fact, faba bean hull supplemented kefir displayed the overall highest SCFAs production among all samples.

\subsection{Kefir (ORAC) antioxidant activity}

Storage time had minimal effects on kefir antioxidant activity, except for inulin supplemented kefir where the variation among storage days was highly significant $(P<0.001)$. Peak antioxidant activity was generally reached on days 14 or 21 of storage (Fig. 3). Antioxidant activity of kefir decreased in the following order: $\mathrm{TF}>\mathrm{WF}>\mathrm{CF} \geq \mathrm{CP} \geq \mathrm{IN}>\mathrm{MCP}$ $>\mathrm{K}$ during the storage period. The high antioxidant activity of the faba bean hull supplemented kefir probably originates from its high phenolic content. Differences between faba bean cotyledon, chickpea and inulin supplemented kefir were not significant, particularly between 1 - 14 days storage and may therefore be considered to exhibit similar behavior.

\section{Conclusion}

Kefir storage has several components, some of which were investigated in this study relative to pulse supplementation. Storage time contributed the most to variability in microbial growth, TTA and $\mathrm{pH}$, production of organic acid and proteolytic activity, whereas the type/source of pulse supplementation determined kefir antioxidant activity. In this context, faba bean hull supplementation would be preferred for its rich total phenolics, phenolic compounds (gallic and protocatechuic acids), flavonoids (catechin, epicatechin and rutin) and antioxidant activity. Moreover, increase in microbial count during kefir storage (day 1 - 28) favored supplementation with faba bean cotyledon, chickpea flour and chickpea mucilage that may be considered as efficient prebiotics. Substantially influenced the production of SCFA and 
307 improved proteolytic activity. Therefore, proper selection of pulse based ingredients is pertinent

308 to kefir storage and shelf-life. Pulse supplemented kefir may combine the probiotic and 309 antioxidant activities to offer synergistic efficacy in blocking cellular oxidation mechanisms

310 and their harmful effects on human health. Thus, pulse ingredients are very potent prebiotics, 311 stimulating the growth of beneficial bacteria and moreover exert strong antioxidant activity due 312 to the presence of pulse-bound polyphenols.

\section{Acknowledgments}

This work was financially supported by Food Science and Nutrition Program, Carleton University, Ottawa, Ontario, Canada. The internship grant of Ph.D student Linda Ould Saadi from Abderrahmane Mira University, Bejaia, Algeria, is gratefully acknowledged. The authors would like to thank Dr Mehri HadiNizhad for her help and support in this investigation. 


\section{References}

314 Agil, R., \& Hosseinian, F. (2012). Dual Functionality of Triticale as a Novel Dietary Source of Prebiotics with Antioxidant Activity in Fermented Dairy Products. Plant Foods for Human Nutrition, 67(1), 88-93. https://doi.org/10.1007/s11130-012-0276-2

Baginsky, C., Peña-Neira, álvaro, Cáceres, A., Hernández, T., Estrella, I., Morales, H., \& Pertuzé, R. (2013). Phenolic compound composition in immature seeds of fava bean (Vicia faba L.) varieties cultivated in Chile. Journal of Food Composition and Analysis, 31(1), 1-6. https://doi.org/10.1016/j.jfca.2013.02.003

Baik, B., \& Han, I. H. (2012). Cooking, roasting, and fermentation of chickpeas, lentils, peas, and soybeans for fortification of leavened bread. Cereal Chemistry, 89(6), 269-275.

Bekkara, F., Jay, M., Viricel, M. R., \& Rome, S. (1998). Distribution of phenolic compounds within seed and seedlings of two Vicia faba cvs differing in their seed tannin content, and study of their seed and root phenolic exudations. Plant and Soil, 203(1), 27-36. https://doi.org/10.1023/A:1004365913726

Boudjou, S., Oomah, B. D., Zaidi, F., \& Hosseinian, F. (2013). Phenolics content and antioxidant and anti-inflammatory activities of legume fractions. Food Chemistry, 138(2-3), 1543-1550. https://doi.org/10.1016/j.foodchem.2012.11.108

Boudjou, S., Zaidi, F., Hosseinian, F., \& Oomah, B. D. (2014). Effects of Faba Bean (Vicia faba L.) Flour on Viability of Probiotic Bacteria During Kefir Storage. Journal of Food Research, 3(6), 13. https://doi.org/10.5539/jfr.v3n6p13

Chaieb, N., González, J. L., López-Mesas, M., Bouslama, M., \& Valiente, M. (2011). Polyphenols content and antioxidant capacity of thirteen faba bean (Vicia faba L.) genotypes cultivated in Tunisia. Food Research International, 44(4), 970-977. https://doi.org/10.1016/j.foodres.2011.02.026

Coda, R., Melama, L., Rizzello, C. G., Curiel, J. A., Sibakov, J., Holopainen, U., ... Sozer, N. 
(2015). Effect of air classification and fermentation by Lactobacillus plantarum VTT E133328 on faba bean (Vicia faba L.) flour nutritional properties. International Journal of Food Microbiology, 193, 34-42. https://doi.org/10.1016/j.ijfoodmicro.2014.10.012

341 Crane, M. (2016). Chicory root fiber granted blood glucose health claim in Europe. Nutritional Outlook, April29.

Espírito Santo, A. P. do, Silva, R. C., Soares, F. A. S. M., Anjos, D., Gioielli, L. A., \& Oliveira, M. N. (2010). Açai pulp addition improves fatty acid profile and probiotic viability in yoghurt. International Dairy Journal, 20(6), 415-422. https://doi.org/10.1016/j.idairyj.2010.01.002

Hosseinian, F. S., \& Mazza, G. (2009). Triticale bran and straw: Potential new sources of phenolic acids, proanthocyanidins, and lignans. Journal of Functional Foods, 1(1), 5764. https://doi.org/10.1016/j.jff.2008.09.009

Kök-Taş, T., Seydim, A. C., Ozer, B., \& Guzel-Seydim, Z. B. (2013). Effects of different fermentation parameters on quality characteristics of kefir. Journal of Dairy Science, 96(2), 780-9. https://doi.org/10.3168/jds.2012-5753

Lamaison, J. L. C., \& Carnet, A. (1990). Teneurs en Principaux Flavonoides des Fleurs de Crataegus monogyna Jacq et de Crataegus laevigata (Poiret D. C) en Fonction de la Vegetation,. Pharmaceutica Acta Helvetia, 65, 315-320.

Leite, A. M. O., Leite, D., Del Aguila, E., Alvares, T., Peixoto, R., Miguel, M., ... Paschoalin, V. (2013). Microbiological and chemical characteristics of Brazilian kefir during fermentation and storage processes. Journal of Dairy Science, 96(7), 4149-4159. https://doi.org/10.3168/jds.2012-6263

Möhle, L., Mattei, D., Heimesaat, M. M., Bereswill, S., Fischer, A., Alutis, M., ... Wolf, S. A. (2016). Ly6Chi Monocytes Provide a Link between Antibiotic-Induced Changes in Gut Microbiota and Adult Hippocampal Neurogenesis. Cell Reports, 15(9), 1945-1956. 
https://doi.org/10.1016/j.celrep.2016.04.074

Mokni Ghribi, A., Sila, A., Maklouf Gafsi, I., Blecker, C., Danthine, S., Attia, H., ... Besbes,

S. (2015). Structural, functional, and ACE inhibitory properties of water-soluble polysaccharides from chickpea flours. International Journal of Biological Macromolecules, 75, 276-282. https://doi.org/10.1016/j.ijbiomac.2015.01.037

O’Brien, K. V, Stewart, L. K., Forney, L. a, Aryana, K. J., Prinyawiwatkul, W., \& Boeneke, C. a. (2015). The effects of postexercise consumption of a kefir beverage on performance and recovery during intensive endurance training. Journal of Dairy Science, 98(11), 7446-7449. https://doi.org/http://dx.doi.org/10.3168/jds.2015-9392

Oomah, B. D., Luc, G., Leprelle, C., Drover, J. C., Harrison, J. E., \& Olson, M. (2011). Phenolics, phytic acid, and phytase in Canadian-grown low-tannin faba bean (Vicia faba L.) genotypes. J Agric Food Chem, 59(8), 3763-3771. https://doi.org/10.1021/jf200338b

Prior, R. L., Hoang, H., Gu, L., Wu, X., Bacchiocca, M., Howard, L., ... Jacob, R. (2003). Assays for hydrophilic and lipophilic antioxidant capacity (oxygen radical absorbance capacity (ORACFL)) of plasma and other biological and food samples. Journal of Agricultural and Food Chemistry, 51, 3273-3279.

Quemener, B. (1988). Improvements in the High-pressure Liquid Chromatographic Determination of Amino Sugars and a!-Galactosides in Faba Bean, Lupine, and Pea, 754-759.

Sarmiento-Rubiano, L. A., Zúñiga, M., Pérez-Martínez, G., \& Yebra, M. J. (2007). Dietary supplementation with sorbitol results in selective enrichment of lactobacilli in rat intestine. Research in Microbiology, 158(8-9), 694-701. https://doi.org/10.1016/j.resmic.2007.07.007

SAS Institute Inc. (1990). SAS/STAT user's guide, version 6. (4th ed.). Cary, NC: SAS Institute. 
Shelke, K. (2016). Fat replacers. Prepared Foods, January 20, 80-89.

389 Singleton, V. L., \& Rossi, J. A. (1965). Colorimetry of total phenolic with phosphomolybdicphosphotungstic acid reagents. . American Journal of Enology and Viticulture, 16, 144158.

Sreerama, Y. N., Sashikala, V. B., \& Pratape, V. M. (2010). Variability in the distribution of phenolic compounds in milled fractions of chickpea and horse gram: Evaluation of their

Varga, L., Szigeti, J., \& Gyenis, B. (2006). Influence of chicory inulin on the survival of microbiota of a probiotic fermented milk during refrigerated storage. Annals of Microbiology, 56(2), 139-141.

Xu, B. J., \& Chang, S. K. C. (2007). A comparative study on phenolic profiles and antioxidant activities of legumes as affected by extraction solvents. Journal of Food Science, 72(2). https://doi.org/10.1111/j.1750-3841.2006.00260.x

Zare, F., Champagne, C. P., Simpson, B. K., Orsat, V., \& Boye, J. I. (2012). Effect of the addition of pulse ingredients to milk on acid production by probiotic and yoghurt starter cultures. LWT - Food Science and Technology, 45(2), 155-160. https://doi.org/10.1016/j.lwt.2011.08.012 


\section{Figure Captions}

Fig 1. Bacterial enumeration of kefir ( $K$, control) supplemented with whole faba bean flour $(K+W F)$, faba bean cotyledon $(\mathrm{K}+\mathrm{CF})$, faba bean hull $(\mathrm{K}+\mathrm{TF})$, chickpea flour $(\mathrm{K}+\mathrm{CP})$, chickpea mucilage $(\mathrm{K}+\mathrm{MCP})$, and inulin $(\mathrm{K}+\mathrm{IN})$ during refrigerated storage $\left(4^{\circ} \mathrm{C}, 28\right.$ days $)$.

Fig 2. a) Titratable acidity and b) pH of kefir (K, control) supplemented with whole faba bean flour $(\mathrm{K}+\mathrm{WF})$, faba bean cotyledon $(\mathrm{K}+\mathrm{CF})$, faba bean hull $(\mathrm{K}+\mathrm{TF})$, chickpea flour $(\mathrm{K}+\mathrm{CP})$, chickpea mucilage $(\mathrm{K}+\mathrm{MCP})$, and inulin $(\mathrm{K}+\mathrm{IN})$ during refrigerated storage $\left(4^{\circ} \mathrm{C}, 28\right.$ days $)$.

Fig 3. Antioxidant activity (ORAC value) of kefir (K, control) supplemented with whole faba bean flour $(\mathrm{K}+\mathrm{WF})$, faba bean cotyledon $(\mathrm{K}+\mathrm{CF})$, faba bean hull $(\mathrm{K}+\mathrm{TF})$, chickpea flour $(\mathrm{K}+\mathrm{CP})$, chickpea mucilage $(\mathrm{K}+\mathrm{MCP})$, and inulin $(\mathrm{K}+\mathrm{IN})$ during refrigerated storage $\left(4^{\circ} \mathrm{C}, 28\right.$ days $)$. 
Fig1.

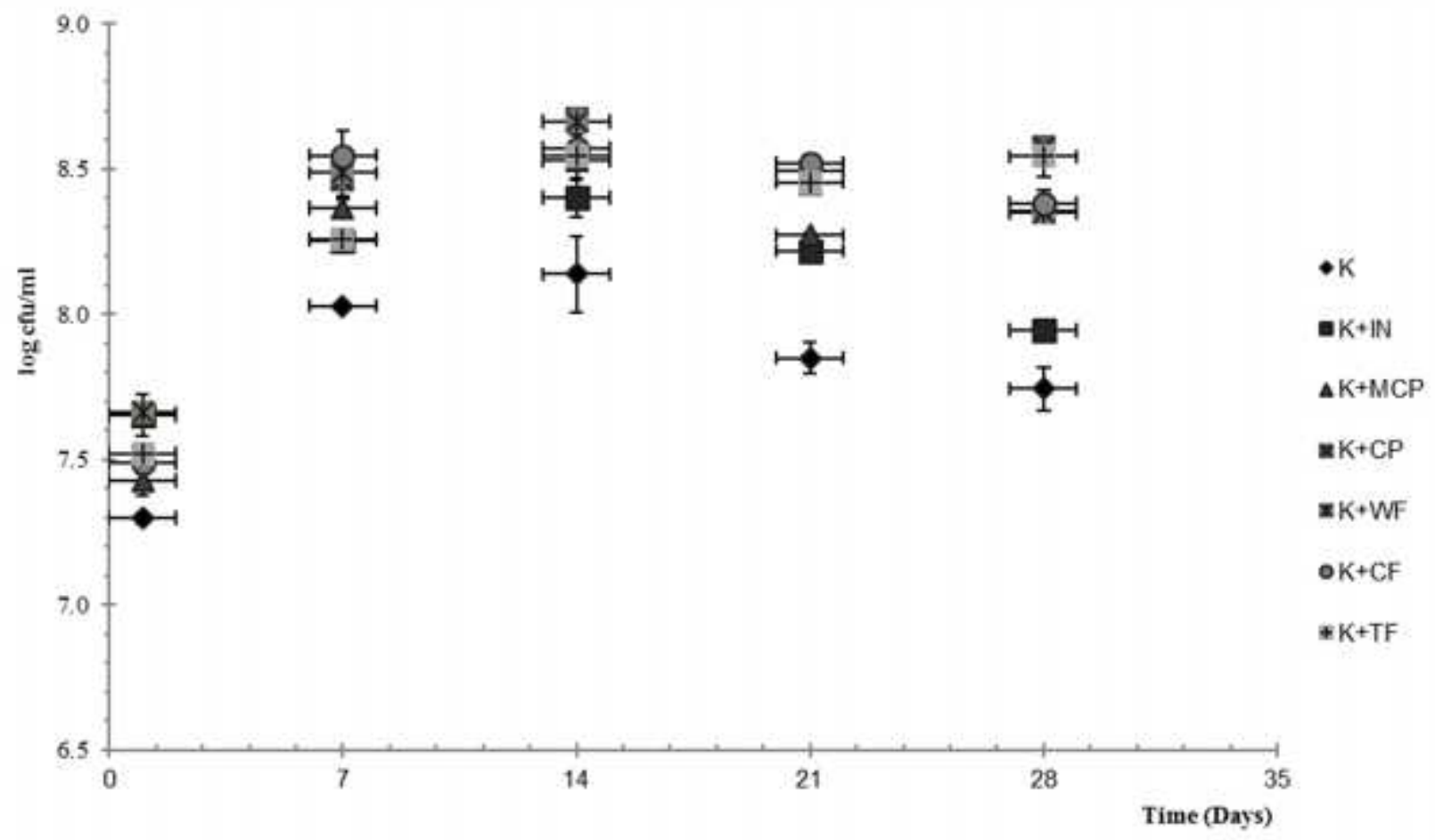


Fig 2. a. b.
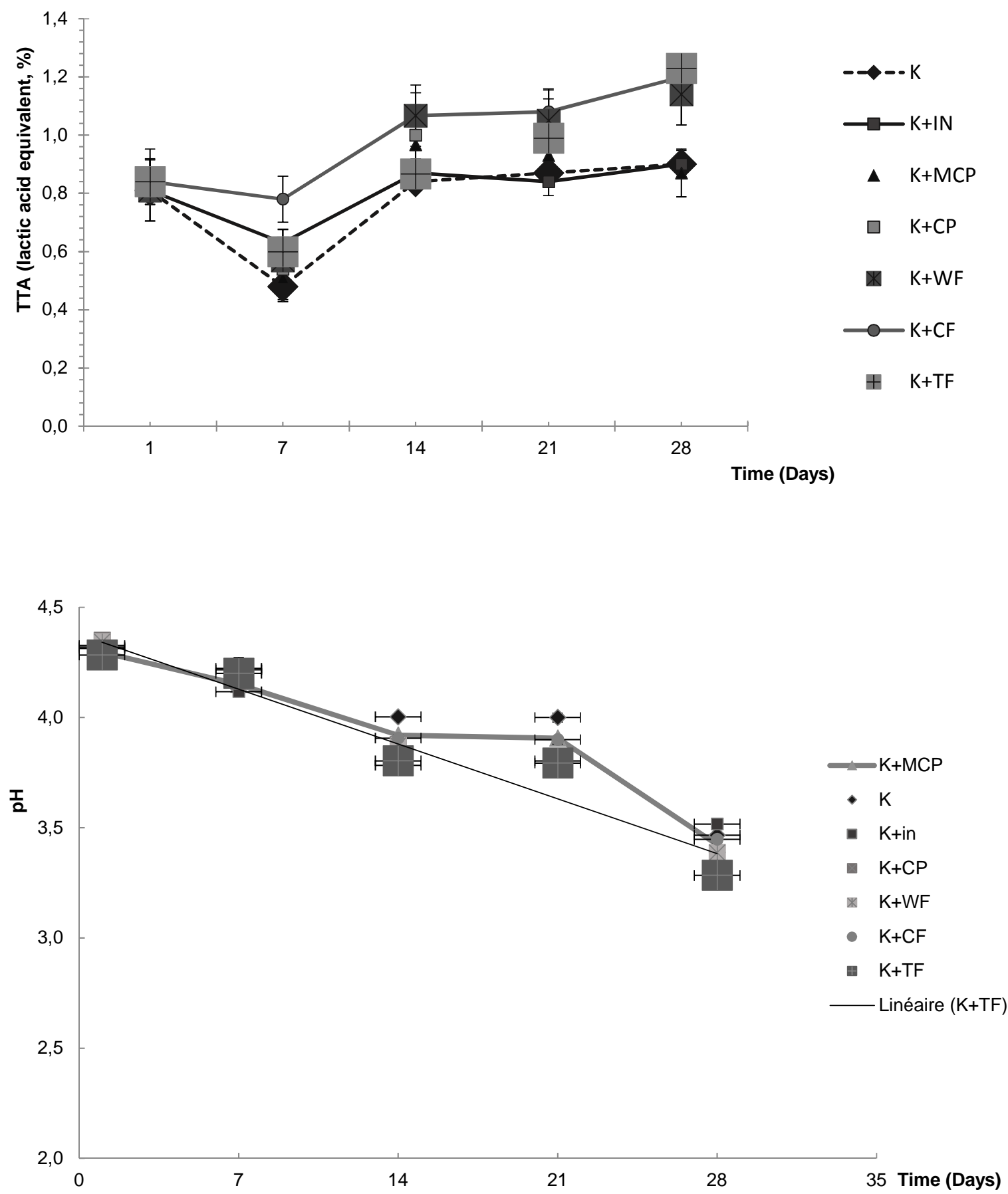
Fig 3.

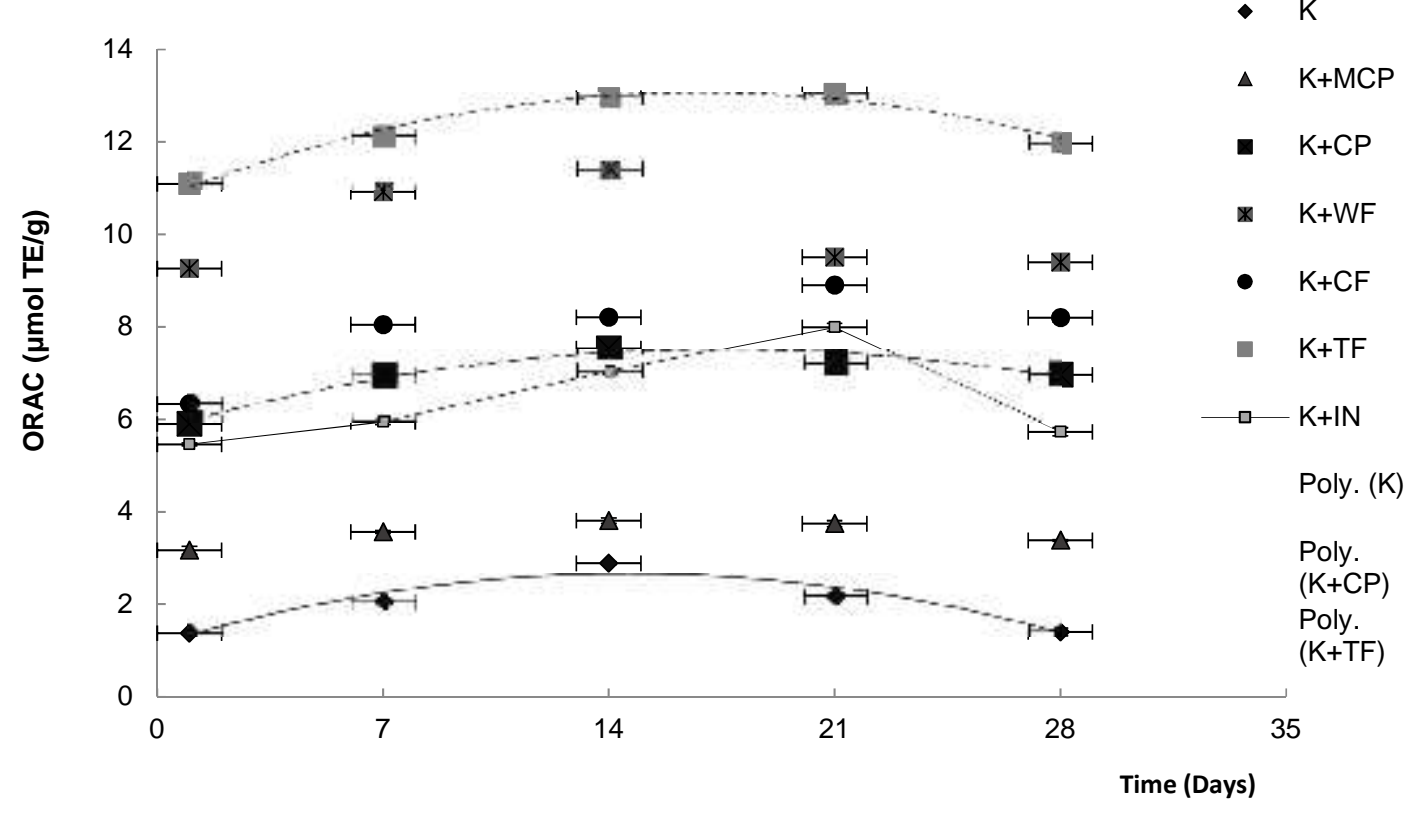


Table 1. Total phenolic, flavonoid contents and antioxidant activities of samples

Each value represents (means \pm standard deviation $n=3$ ). Means in a column with different letters are significantly different $(\mathrm{P}<0.05)$. Total phenolics and flavonoids are expressed in $\mathrm{mg}$ gallic acid and quercetin equivalents/g sample, respectively. ORAC - oxygen radical absorbance capacity values are expressed in mol trolox equivalent/g sample.

Table 2. Phenolic compounds $(\mathrm{mg} / \mathrm{g})$

Each value represents (means \pm standard deviation $n=3$ ). Means in a row with different letters are significantly different $(\mathrm{P}<0.05)$. n.d: not detected. WFB, CF and TF denote whole, cotyledon and hull of faba bean, respectively; CP, chickpea; MCP, chickpea mucilage.

Tabel 3. Proteolytic activities of Kefir samples during storage time at $4{ }^{\circ} \mathrm{C}$

kefir (K, control) supplemented with whole faba bean flour $(\mathrm{K}+\mathrm{WF})$, faba bean cotyledon $(\mathrm{K}+\mathrm{CF})$, faba bean hull $(\mathrm{K}+\mathrm{TF})$, chickpea flour $(\mathrm{K}+\mathrm{CP})$, chickpea mucilage $(\mathrm{K}+\mathrm{MCP})$, and inulin $(\mathrm{K}+\mathrm{IN})$ during refrigerated storage $\left(4{ }^{\circ} \mathrm{C}, 28\right.$ days). Each value represents (means \pm standard deviation $\mathrm{n}=3$ ). Means in a same column with different letters are significantly different $(\mathrm{P}<0.05)$.

Tabel 4. Concentration of Lactic, acetic, propionic and butyric acid in Kefir samples produced by starter cultures in presence of different supplementations

kefir (K, control) supplemented with whole faba bean flour $(\mathrm{K}+\mathrm{WF})$, faba bean cotyledon $(\mathrm{K}+\mathrm{CF})$, faba bean hull $(\mathrm{K}+\mathrm{TF})$, chickpea flour $(\mathrm{K}+\mathrm{CP})$, chickpea mucilage $(\mathrm{K}+\mathrm{MCP})$, and inulin $(\mathrm{K}+\mathrm{IN})$ during refrigerated storage $\left(4{ }^{\circ} \mathrm{C}, 28\right.$ days). Each value represents (means \pm standard deviation $n=3$ ). Means in a same column with different letters are significantly different $(\mathrm{P}<0.05)$. 
Table 1.

\begin{tabular}{lllll}
\hline Sample & ID & Phenolics & Flavonoids & ORAC \\
\hline Faba bean & & & & \\
Whole & WF & $14.65 \pm 0.4 \mathrm{~b}$ & $0.148 \pm 0.003 \mathrm{~b}$ & $175.29 \pm 6.4 \mathrm{~b}$ \\
Hull & TF & $57.53 \pm 1.7 \mathrm{a}$ & $0.79 \pm 0.02 \mathrm{a}$ & $265.97 \pm 5.4 \mathrm{a}$ \\
Cotyledon & CF & $6.09 \pm 0.1 \mathrm{c}$ & $0.022 \pm 0.0005 \mathrm{~d}$ & $90.63 \pm 1.2 \mathrm{c}$ \\
Chickpea & & & & \\
Whole & $\mathrm{CP}$ & & & \\
Mucilage & $\mathrm{MCP}$ & $5.84 \pm 0.2 \mathrm{~d}$ & $0.027 \pm 0.003 \mathrm{~d}$ & $75.74 \pm 4.1 \mathrm{c}$ \\
& & & & \\
\end{tabular}


Table 2.

\section{Phenolic compounds}

Phenolic acids

Caffeic

Chlorogenic

Gallic

$O$-Coumaric

$P$-Coumaric

p-Hydroxybenzoic

Protocatechuic

Pyrogallol

Synapic

Vanillic

$\Sigma$ Phenolic adids

Flavonoids

Apigenin

Catechin

Epicatechin

Epicatechine gallate

Kaempferol

Myricetin

Quercetin

Quercetin 3 $\beta$-glucoside

Rutin

¿Flavonoids

Ratio Phenolics/Flavonoids

\section{WFB}

CF

TF

CP

MCP

$0.340 \pm 0.02 b$

$0.346 \pm 0.03 a$

$0.297 \pm 0.1 \mathrm{c}$

n.d

n.d

$2.013 \pm 0.2 b$

$2.016 \pm 0.4 a$

n.d

n.d

n.d

$0.381 \pm 0.03 b$

$0.367 \pm 0.02 c$

$0.389 \pm 0.3 a$

$0.349 \pm 0.4 d$

$0.001 \pm 0.0003 e$

n.d

n.d

$0.045 \pm 0.03 a$

n.d

n.d

n.d

$0.040 \pm 0.001 a$

n.d

$0.327 \pm 0.3 a$

n.d

$0.554 \pm 0.02 c$

n.d

$0.094 \pm 0.001 \mathrm{e}$

n.d

$0.0124 \pm 0.01 \mathrm{c}$

$0.00001 \pm 0.00002 d$

$0.0155 \pm 0.001 b$

$0.0164 \pm 0.004 a$

n.d

$4.252 a$

$2.242 \mathrm{c}$

$0.456 d$

$0.483 d$

$4.022 b$

n.d

$0.239 \pm 0.003 b$

$0.076 \pm 0.009 d$

$0.955 \pm 0.04$

$0.222 \pm 0.06 \mathrm{c}$

n.d

$0.157 \pm 0.002 c$

n.d

$0.408 \pm 0.2 a$

n.d

$0.189 \pm 0.1 b$

$0.154 \pm 0.002 a$

$0.109 \pm 0.09 c$

$0.115 \pm 0.01 b$

n.d

n.d

n.d

n.d

$0.142 \pm 0.001 a$

n.d

n.d

n.d

n.d

n.d

$0.390 \pm 0.02 a$

n.d

$0.509 \pm 0.05 b$

n.d

n.d

$0.523 \pm 0.02 a$

n.d

$0.208 \pm 0.08 a$

n.d

n.d

n.d

n.d

$0.238 \pm 0.06 c$

$0.261 \pm 0.01 b$

$0.444 \pm 0.05$

n.d

n.d

$1.504 b$

$0.446 d$

$2.112 a$

$1.165 \mathrm{c}$

$0.188 \mathrm{e}$

$2.67 b$

$9.54 a$

$1.06 \mathrm{c}$

$0.39 d$ 
Tabel 3.

\begin{tabular}{lllllll}
\hline $\begin{array}{l}\text { Samples (Abs } \\
340)\end{array}$ & 1 & 7 & 14 & 21 & 28 & Mean \\
\hline $\mathrm{K}$ & $0.61 \pm 0.06 \mathrm{c}$ & $1.08 \pm 0.2 \mathrm{bc}$ & $0.94 \pm 0.03 \mathrm{e}$ & $1.30 \pm 0.3 \mathrm{c}$ & $1.17 \pm 0.01 \mathrm{c}$ & $1.02 \mathrm{Z}$ \\
$\mathrm{K}+\mathrm{in}$ & $0.95 \pm 0.05 \mathrm{~b}$ & $0.98 \pm 0.08 \mathrm{c}$ & $1.28 \pm 0.01 \mathrm{~cd}$ & $1.35 \pm 0.03 \mathrm{~b}$ & $1.17 \pm 0.02 \mathrm{c}$ & $1.15 \mathrm{X}$ \\
$\mathrm{K}+\mathrm{wf}$ & $1.13 \pm 0.03 \mathrm{a}$ & $1.20 \pm 0.3 \mathrm{ab}$ & $1.31 \pm 0.08 \mathrm{bc}$ & $1.42 \pm 0.03 \mathrm{a}$ & $1.23 \pm 0.01 \mathrm{~b}$ & $1.26 \mathrm{~W}$ \\
$\mathrm{~K}+\mathrm{cf}$ & $1.19 \pm 0.07 \mathrm{a}$ & $1.09 \pm 0.08 \mathrm{bc}$ & $1.37 \pm 0.02 \mathrm{ab}$ & $1.44 \pm 0.03 \mathrm{a}$ & $1.23 \pm 0.02 \mathrm{~b}$ & $1.26 \mathrm{~W}$ \\
$\mathrm{~K}+\mathrm{tf}$ & $0.94 \pm 0.1 \mathrm{~b}$ & $1.04 \pm 0.04 \mathrm{c}$ & $1.28 \pm 0.02 \mathrm{~cd}$ & $1.29 \pm 0.03 \mathrm{c}$ & $1.28 \pm 0.03 \mathrm{a}$ & $1.17 \mathrm{X}$ \\
$\mathrm{K}+\mathrm{cp}$ & $1.07 \pm 0.05 \mathrm{ab}$ & $1.25 \pm 0.05 \mathrm{a}$ & $1.42 \pm 0.009 \mathrm{a}$ & $1.44 \pm 0.02 \mathrm{a}$ & $1.19 \pm 0.008 \mathrm{c}$ & $1.27 \mathrm{~W}$ \\
$\mathrm{~K}+\mathrm{mcp}$ & $0.74 \pm 0.01 \mathrm{c}$ & $0.99 \pm 0.008 \mathrm{c}$ & $1.23 \pm 0.02 \mathrm{~d}$ & $1.31 \pm 0.01 \mathrm{bc}$ & $1.18 \pm 0.001 \mathrm{c}$ & $1.09 \mathrm{Y}$ \\
Mean & $0.95 \mathrm{E}$ & $1.09 \mathrm{D}$ & $1.26 \mathrm{~B}$ & $1.37 \mathrm{~A}$ & $1.21 \mathrm{C}$ & 1.17 \\
\hline
\end{tabular}


Tabel 4.

\begin{tabular}{|c|c|c|c|c|c|c|}
\hline \multirow[t]{2}{*}{$\begin{array}{l}\text { Sample } \\
(\mu \mathrm{mol} / \mathrm{g} \\
\text { of Kefir) }\end{array}$} & \multicolumn{5}{|c|}{ Storage time (days) } & \multirow[b]{2}{*}{ Mean } \\
\hline & 1 & 7 & 14 & 21 & 28 & \\
\hline \multicolumn{7}{|c|}{ Lactic acid } \\
\hline $\mathrm{K}$ & $5.26 \pm 0.07 \mathrm{~g}$ & $8.27 \pm 0.3 \mathrm{c}$ & $7.18 \pm 0.4 \mathrm{c}$ & $6.63 \pm 0.5 \mathrm{~d}$ & $5.00 \pm 0.4 \mathrm{e}$ & $6.47 \mathrm{Z}$ \\
\hline $\mathrm{K}+\mathrm{in}$ & $7.24 \pm 0.1 \mathrm{e}$ & $8.35 \pm 0.3 \mathrm{c}$ & $8.25 \pm 0.06 \mathrm{bc}$ & $7.26 \pm 0.2 \mathrm{~d}$ & $6.94 \pm 0.3 \mathrm{~cd}$ & $7.61 \mathrm{Y}$ \\
\hline $\mathrm{K}+\mathrm{wf}$ & $8.25 \pm 0.01 \mathrm{c}$ & $9.72 \pm 0.2 \mathrm{ab}$ & $11.12 \pm 0.2 \mathrm{a}$ & $9.14 \pm 0.1 b$ & $7.41 \pm 0.6 \mathrm{bc}$ & $9.13 \mathrm{~W}$ \\
\hline $\mathrm{K}+\mathrm{cf}$ & $6.44 \pm 0.2 \mathrm{f}$ & $9.41 \pm 0.3 b$ & $8.23 \pm 0.9 b c$ & $6.72 \pm 0.2 \mathrm{~d}$ & $6.66 \pm 0.3 \mathrm{~d}$ & $7.49 \mathrm{Y}$ \\
\hline $\mathrm{K}+\mathrm{tf}$ & $8.07 \pm 0.07 \mathrm{~d}$ & $8.64 \pm 0.4 \mathrm{c}$ & $8.47 \pm 0.8 b$ & $8.88 \pm 0.3 b c$ & $7.62 \pm 0.2 b$ & $8.34 \mathrm{X}$ \\
\hline $\mathrm{K}+\mathrm{cp}$ & $9.00 \pm 0.09 \mathrm{~b}$ & $10.22 \pm 0.4 \mathrm{a}$ & $11.32 \pm 0.8 \mathrm{a}$ & $10.88 \pm 0.3 \mathrm{a}$ & $8.57 \pm 0.02 \mathrm{a}$ & $10.00 \mathrm{~V}$ \\
\hline $\mathrm{K}+\mathrm{mcp}$ & $9.21 \pm 0.01 \mathrm{a}$ & $9.63 \pm 0.2 \mathrm{ab}$ & $8.72 \pm 0.6 \mathrm{~b}$ & $8.35 \pm 0.2 c$ & $7.10 \pm 0.2 \mathrm{bcd}$ & $8.60 \mathrm{X}$ \\
\hline Mean & $7.64 \mathrm{C}$ & $9.18 \mathrm{~A}$ & $9.04 \mathrm{~A}$ & $8.27 \mathrm{~B}$ & $7.04 \mathrm{D}$ & \\
\hline \multicolumn{7}{|c|}{ Acetic acid } \\
\hline $\mathrm{K}$ & $1.22 \pm 0.02 \mathrm{~d}$ & $1.77 \pm 0.01 \mathrm{~d}$ & $1.83 \pm 0.04 \mathrm{e}$ & $0.81 \pm 0.02 \mathrm{e}$ & $0.60 \pm 0.04 \mathrm{e}$ & $1.24 \mathrm{Y}$ \\
\hline $\mathrm{K}+\mathrm{in}$ & $1.63 \pm 0.01 \mathrm{c}$ & $2.05 \pm 0.03 \mathrm{c}$ & $1.84 \pm 0.03 \mathrm{e}$ & $1.44 \pm 0.05 \mathrm{c}$ & $0.82 \pm 0.05 \mathrm{~d}$ & $1.56 \mathrm{~W}$ \\
\hline $\mathrm{K}+\mathrm{wf}$ & $1.60 \pm 0.02 \mathrm{c}$ & $1.79 \pm 0.03 \mathrm{~d}$ & $2.01 \pm 0.03 \mathrm{~d}$ & $0.99 \pm 0.03 \mathrm{~d}$ & $0.57 \pm 0.03 \mathrm{e}$ & $1.39 \mathrm{X}$ \\
\hline $\mathrm{K}+\mathrm{cf}$ & $1.22 \pm 0.03 \mathrm{~d}$ & $1.36 \pm 0.03 \mathrm{e}$ & $1.63 \pm 0.03 \mathrm{f}$ & $0.81 \pm 0.04 \mathrm{e}$ & $0.82 \pm 0.04 \mathrm{~d}$ & $1.17 \mathrm{Z}$ \\
\hline $\mathrm{K}+\mathrm{tf}$ & $1.01 \pm 0.05 \mathrm{e}$ & $2.43 \pm 0.04 \mathrm{a}$ & $2.66 \pm 0.04 \mathrm{~b}$ & $2.06 \pm 0.05 \mathrm{a}$ & $2.06 \pm 0.05 \mathrm{a}$ & $2.04 \mathrm{U}$ \\
\hline $\mathrm{K}+\mathrm{cp}$ & $2.31 \pm 0.02 \mathrm{a}$ & $2.43 \pm 0.03 \mathrm{a}$ & $2.82 \pm 0.03 \mathrm{a}$ & $1.84 \pm 0.05 b$ & $1.63 \pm 0.04 \mathrm{~b}$ & $2.21 \mathrm{~T}$ \\
\hline $\mathrm{K}+\mathrm{mcp}$ & $1.92 \pm 0.02 b$ & $2.17 \pm 0.04 \mathrm{~b}$ & $2.17 \pm 0.03 \mathrm{c}$ & $2.04 \pm 0.06 \mathrm{a}$ & $1.43 \pm 0.05 \mathrm{c}$ & $1.95 \mathrm{~V}$ \\
\hline Mean & $1.56 \mathrm{C}$ & $2.00 \mathrm{~B}$ & $2.14 \mathrm{~A}$ & $1.43 \mathrm{D}$ & $1.13 \mathrm{E}$ & \\
\hline \multicolumn{7}{|c|}{ Propionic acid } \\
\hline K & $0.18 \pm 0.01 b$ & $0.17 \pm 0.03 b$ & $0.20 \pm 0.02 \mathrm{ab}$ & $0.20 \pm 0.02 b$ & $0.14 \pm 0.02 \mathrm{ab}$ & $0.18 \mathrm{YZ}$ \\
\hline $\mathrm{K}+\mathrm{in}$ & $0.20 \pm 0.05 \mathrm{ab}$ & $0.21 \pm 0.05 \mathrm{ab}$ & $0.20 \pm 0.05 \mathrm{ab}$ & $0.25 \pm 0.05 \mathrm{ab}$ & $0.17 \pm 0.04 \mathrm{ab}$ & $0.21 \mathrm{XY}$ \\
\hline $\mathrm{K}+\mathrm{wf}$ & $0.17 \pm 0.02 b$ & $0.20 \pm 0.01 \mathrm{ab}$ & $0.19 \pm 0.02 \mathrm{~b}$ & $0.11 \pm 0.02 \mathrm{c}$ & $0.10 \pm 0.02 b$ & $0.15 \mathrm{Z}$ \\
\hline $\mathrm{K}+\mathrm{cf}$ & $0.20 \pm 0.02 \mathrm{ab}$ & $0.22 \pm 0.01 \mathrm{ab}$ & $0.26 \pm 0.02 \mathrm{a}$ & $0.26 \pm 0.03 \mathrm{ab}$ & $0.18 \pm 0.02 b$ & $0.22 \mathrm{WX}$ \\
\hline $\mathrm{K}+\mathrm{tf}$ & $0.26 \pm 0.02 \mathrm{a}$ & $0.26 \pm 0.04 \mathrm{a}$ & $0.26 \pm 0.05 \mathrm{a}$ & $0.31 \pm 0.06 \mathrm{a}$ & $0.14 \pm 0.07 \mathrm{ab}$ & $0.25 \mathrm{~W}$ \\
\hline $\mathrm{K}+\mathrm{cp}$ & $0.20 \pm 0.04 \mathrm{ab}$ & $0.21 \pm 0.03 \mathrm{ab}$ & $0.21 \pm 0.04 \mathrm{ab}$ & $0.20 \pm 0.03 b$ & $0.16 \pm 0.05 b$ & $0.20 \mathrm{XY}$ \\
\hline $\mathrm{K}+\mathrm{mcp}$ & $0.17 \pm 0.03 b$ & $0.17 \pm 0.03 b$ & $0.22 \pm 0.02 \mathrm{ab}$ & $0.20 \pm 0.04 b$ & $0.17 \pm 0.03 b$ & $0.19 \mathrm{Y}$ \\
\hline Mean & $0.20 \mathrm{~A}$ & $0.21 \mathrm{~A}$ & $0.22 \mathrm{~A}$ & $0.22 \mathrm{~A}$ & $0.15 \mathrm{~B}$ & \\
\hline \multicolumn{7}{|c|}{ Butyric acid } \\
\hline $\mathrm{K}$ & $0.52 \pm 0.03 \mathrm{c}$ & $0.60 \pm 0.08 \mathrm{c}$ & $0.71 \pm 0.03 \mathrm{~d}$ & $0.76 \pm 0.02 \mathrm{a}$ & $0.45 \pm 0.02 \mathrm{~cd}$ & $0.61 \mathrm{Y}$ \\
\hline $\mathrm{K}+\mathrm{in}$ & $0.50 \pm 0.05 \mathrm{c}$ & $0.68 \pm 0.05 b c$ & $0.76 \pm 0.03 d$ & $0.57 \pm 0.04 b$ & $0.39 \pm 0.05 \mathrm{~d}$ & $0.58 \mathrm{YZ}$ \\
\hline $\mathrm{K}+\mathrm{wf}$ & $0.52 \pm 0.02 c$ & $0.69 \pm 0.03 b$ & $0.99 \pm 0.3 \mathrm{a}$ & $0.71 \pm 0.02 \mathrm{a}$ & $0.58 \pm 0.05 \mathrm{~b}$ & $0.70 \mathrm{X}$ \\
\hline $\mathrm{K}+\mathrm{cf}$ & $0.39 \pm 0.03 \mathrm{~d}$ & $0.71 \pm 0.04 \mathrm{~b}$ & $0.71 \pm 0.01 \mathrm{~d}$ & $0.54 \pm 0.03 b$ & $0.49 \pm 0.04 \mathrm{bcd}$ & $0.57 \mathrm{Z}$ \\
\hline $\mathrm{K}+\mathrm{tf}$ & $0.73 \pm 0.04 \mathrm{a}$ & $0.81 \pm 0.02 \mathrm{a}$ & $0.89 \pm 0.06 \mathrm{bc}$ & $0.59 \pm 0.09 b$ & $0.48 \pm 0.03 \mathrm{bcd}$ & $0.70 \mathrm{X}$ \\
\hline $\mathrm{K}+\mathrm{cp}$ & $0.61 \pm 0.04 \mathrm{~b}$ & $0.82 \pm 0.04 a$ & $0.92 \pm 0.04 \mathrm{~b}$ & $0.79 \pm 0.05 \mathrm{a}$ & $0.54 \pm 0.07 \mathrm{bc}$ & $0.74 X$ \\
\hline $\mathrm{K}+\mathrm{mcp}$ & $0.57 \pm 0.03 b c$ & $0.83 \pm 0.03 \mathrm{a}$ & $0.85 \pm 0.01 \mathrm{c}$ & $0.72 \pm 0.05 \mathrm{a}$ & $0.69 \pm 0.05 \mathrm{a}$ & $0.73 X$ \\
\hline Mean & $0.55 \mathrm{D}$ & $0.73 \mathrm{~B}$ & $0.83 \mathrm{~A}$ & $0.67 \mathrm{C}$ & $0.52 \mathrm{E}$ & \\
\hline
\end{tabular}

